\title{
Elegance in REBT: Reflections on the Ellis and Dryden Sessions with Jane
}

\author{
Windy Dryden
}

Published online: 6 August 2010

(C) Springer Science+Business Media, LLC 2010

\begin{abstract}
In this article, I reflect on the one-off sessions that Albert Ellis and I did with Jane. It is clear that Albert Ellis's work is an example of inelegant or general REBT, while my session is an example of specific or elegant REBT. First, I speculate on the possible reasons why Ellis practised inelegant REBT is his session. Then, I critique my own work covering both what I like and dislike about my work with Jane. I conclude that while I practised elegant REBT with her, my work was flawed in two major respects: (i) failure to target consistently Jane's demands for change and (ii) introducing changes at $\mathrm{A}$ while disputing irrational beliefs at $\mathrm{B}$.
\end{abstract}

Keywords REBT - Elegance vs. inelegance · Focus vs. comprehensiveness

\section{Introduction}

As Hank Robb notes in his paper, this is a unique opportunity to compare the work of the founder of REBT and one of its leading figures with the same client. As John Minor has focused on the interview conducted by Albert Ellis in his paper, I will focus on and critique my own work with Jane. However, I would like to make a number of observations on Albert Ellis's interview with Jane.

\section{Some General Observations on Ellis's Interview with Jane}

Initially, when I heard and read the transcript of this interview I was struck by the extent of Ellis's emphasis on helping Jane to make her decision rather than on the disturbed emotions that might have served to prevent her from making this decision.

W. Dryden (ه)

Goldsmiths College, Goldsmiths University of London, New Cross, London SE14 6NW, UK e-mail: windy@thedrydens.clara.net 
Here was the founder of REBT, not focusing much on $\mathrm{B}$ and $\mathrm{C}$ in the $\mathrm{ABC}$ framework!

Let me speculate on some possible reasons for Ellis's focus. First, Ellis did not know before this interview that his work was going to be published or that there was a possibility that it would be published. I know from sitting in on Ellis's groups at the Albert Ellis Institute that he spent more time helping his clients solve their practical dilemmas than his writings might suggest. However, of course, if asked, Ellis would have said that his work with Jane was an example of his practising general or inelegant REBT rather than specific or elegant REBT.

My hunch is that if Ellis was conducting his session with Jane in public or if he knew that his work was going to be later held up to professional scrutiny then he would have better approximated specific REBT with its greater focus on disturbed emotions and behavior and the irrational beliefs that are deemed to underpin them.

However, he did give permission for his interview to be studied in this series of articles, thus demonstrating his openness to having his work scrutinised and, if he were still alive, he would have spoken for himself.

My second guess about Ellis's general REBT focus is that he knew that Jane was the girlfriend of an REBT therapist and consequently, he might have thought that she knew how to use specific REBT with herself. There is, however, no evidence in his interview to support this view.

Third, Ellis may have thought that he would have the chance later to work with Jane on her emotional problems and thus, he would concentrate on practical problem-solving in the interview. There is some evidence for this view. Thus, towards the end of his interview with Jane at line 291 and lines 303-305, Ellis discussed the importance of not disturbing yourself and this suggests that he knew that Jane was disturbing herself and offered her the opportunity of later phone sessions to discuss them.

\section{Some General Observations on My Interview with Jane}

When I was approached by Jane to do a one-off therapy session with Jane, she did tell me that she already had a similar session with Ellis. I remember thinking two things in response to Jane's request. First, I thought that Jane's request to consult with me was unusual given that she had already had a session with Ellis. Second, I thought that since Jane wanted to record a session with me and had recorded her session with Ellis, that it would be interesting later to compare my session with Ellis's. However, I should stress that this was only a flicker of an idea, but it did mean that I experienced an extra motivation to do a good job, which Ellis possibly lacked. Perhaps this is why my session is more obviously an example of elegant or specific REBT. However, as I will show, my session is not a very elegant form of elegant REBT.

\section{Understanding the Context of Jane's Indecision}

Both Ellis and I spend quite a bit of session time trying to understand the context in which Jane was experiencing difficulty making her decision. It is clear that this is 
not a situation where the therapist can focus on one client problem, but one in which there are number of issues that underpinned this client's decision-making difficulty.

\section{Jane's Disturbance}

As the session unfolded, I brought out and discussed a number of emotional problems that Jane had which underpinned the difficulty she had with decisionmaking. These were as follows:

- Jane's anxiety about losing her kids, friends and community if she chose L

- Jane's anxiety about her kids thinking that she had rejected them if she chose L and the guilt she would experienced if they thought this

- Jane's anxiety about losing L if she chose her current life situation

- Jane's feelings of guilt about acting selfishly

- Jane's reluctance to choose L because she thinks she needs a guarantee that L would not reject her later if she chose him

- Jane's reluctance to make a decision because doing so means losing something important when she believes that she must have it all

- Jane's belief that she needs to make a quick decision in response to L's pressure

\section{The Dilemma of Being Comprehensive vs. Being Focused}

I do some work on all of the above-mentioned issues, but I tend to switch from problem to problem as Jane discloses them. In one-off sessions when the situation is complex, the therapist is faced with the choice of being comprehensive and spending some time on all revealed emotional problems or of focusing on one major problem to the exclusion of all else. I chose the former tack, but wonder what the outcome would have been if I chose the latter. Thus, in hindsight I could have asked Jane; "Which one issue shall we focus on, the resolution of which would help you make a decision?" This would have given the session a greater focus and facilitated Jane's decision-making.

While there are a number of problems with the way I intervened in the session which I will discuss below, I am pleased with the session in a number of respects.

\section{What I Like about My Session with Jane}

There are a number of things that I like about my session with Jane.

1. I helped Jane to articulate the seven areas of disturbance that underpinned her indecision (listed above). Even though I allowed Jane to wander from problem to problem when I could have focused more intensively on her main areas of difficulty, at least I helped her to understand the emotional problems that were blocking her from making a decision. 
2. I taught Jane a number of important points. Thus:

- At line 54 (this and all subsequent line numbers refer to my interview with Jane), I explained REBT's focus on disturbance and related goal which in Jane's case was to her be as rational as she can be about the two horns of her dilemma.

- At line 80, I taught Jane the B-C connection.

- At line 82 and again at lines 94-98, I taught Jane that sadness is a healthy negative emotion related to non-awfulising and High Frustration Tolerance (HFT) rational beliefs. I also showed her the difference between her nonawfulising rational belief and its irrational belief awfulising alternative.

- At line 140, I explained to Jane the REBT conceptualisation of guilt and used this to see if this is what she was thinking and feeling.

3. I checked for the presence of secondary disturbance. REBT theory argues that people often disturb themselves about their original psychological disturbance (e.g. Ellis and MacLaren 1998) and I checked for the possibility that Jane was doing this at lines 60-64. As Jane indicated that she did not have secondary disturbance, I proceeded to focus on her primary disturbance.

4. I summarised my work with Jane at various points during the session. In one-off sessions, particularly when therapist and client cover a lot of ground, it is important for the therapist to summarise periodically the substantive issues that have been raised during the session. Thus, I summarised my work with Jane at line 150 and then again at lines 520-525.

5. I utilised Jane's view that she is a survivor (which she first brings up at line 230) to help her to consolidate her rational beliefs. I do this at line 208 and at line 210.

\section{What I Don't Like about My Session with Jane}

There are a number of things that I don't like about my session with Jane where I introduce a degree of inelegance into my elegant approach to REBT.

\section{Focus Insufficiently on Jane's Rigid Demands}

REBT theory emphasises the importance of irrational beliefs in underpinning psychological disturbance and stresses (e.g. Ellis 1994) that rigid demands are at the core of such disturbance. In addition, the most elegant REBT view is that the three other irrational beliefs (i.e. awfulising beliefs, Low Frustration Toleration (LFT) beliefs and self/other depreciation beliefs) are derived from these rigid demands. Thus, the most elegant approach to a client's irrational and rational beliefs is to focus primarily on rigid demands and their rational alternative, non-dogmatic preferences, unless there is a good reason not to. My work with Jane is not characterised by such elegance. Thus, there are a number of times where I chose to 
focus on the derivatives of Jane's rigid demands and non-dogmatic preferences rather than on the demands and non-dogmatic preferences themselves. Thus:

- At line 155, I focused on Jane's non-awfulising and HFT beliefs about dealing with loss rather than on her non-dogmatic preferences which I do not mention.

- At line 94, I made the rational belief-healthy negative emotion connection, by linking a non-awfulising belief with sadness instead of using a non-dogmatic preference to show Jane this relationship.

- At lines 105-111, I went along with Jane's stated LFT belief about losing her kids, disputed it and encouraged her to develop an HFT belief instead of helping her to see the role of her rigid demand, disputing that belief and encouraging her to develop a non-dogmatic preference.

- At lines 118-121, I again disputed Jane's LFT belief about losing her kids rather than helping her to identify and dispute her demand about this loss.

- At line 142, I disputed Jane's self-depreciation belief underlying her guilt rather than her unidentified demand about acting selfishly.

- At line 196, I disputed Jane's LFT about losing everything and not her unidentified demand.

- At line 204, I asked Jane to construct a life based on an HFT belief rather than her unidentified non-dogmatic preference.

- At line 220 in the devil's advocate disputing sequence, I disputed Jane's selfdepreciation belief about acting selfishly rather than her unidentified rigid demand.

- There were times, however, when I did focus on Jane's rigid demands. Thus:

- At lines 174-181, I disputed Jane's demand about having it all.

- At lines 200-203, I disputed Jane's demand about L keeping his promise.

- At line 230, as part of the devil's advocate disputing sequence, I disputed Jane's demand about uncertainty about what will happen with L should she choose him over her family and community.

- At line 239, I disputed Jane's demand about going along with L's pressure.

In summary, I focused on Jane's demands and non-dogmatic preferences about $50 \%$ of the time that I focused on her derivatives from these beliefs. This, in summary, constitutes inelegant elegant REBT!!

\section{Disputing Irrational Beliefs while Simultaneously Suggesting Changes in A}

One of the things that struck me when I read the transcript of my session with Jane was the number of times I suggested changes in A while working with Jane on disputing her irrational beliefs at $\mathrm{B}$. This is a practice that I discourage REBT trainees from emulating since it confuses matters for both therapist and clients and makes it difficult for the therapist to judge whether changes made by the client can be attributed to changes at B or to changes at A. In short, this is the aspect of the session I was most disappointed about. Here are the occasions when I did this. 
- At line 86, I changed A while disputing Jane's irrational belief about losing L. The loss of L by him dying (introduced by me) does not equate with the loss brought about by her choosing her family/community. It would have been better if I kept with loss as defined by her.

- At lines 112-121, I disputed Jane's LFT belief at B by changing A again. This time I changed A to leaving her kids to keep them alive instead of leaving her kids because she had chosen L. I rescued matters somewhat at line 122 by stressing that within my scenario her kids do not know that she has rejected them, but the real issue at $\mathrm{A}$ about which she is disturbing herself is that her kids know that she has chosen L over them. Keeping this A to the fore, while I disputed Jane's irrational belief, would have been the most elegant strategy.

- At line 126, I changed A again so that Jane's kids think that she is rejecting them but that she knows that she is keeping them alive. She stated that she could tolerate their rejection under these circumstances. This is not such a bad intervention in that it helped me to hypothesise that one element of her disturbance was based on the inference at A that she would be acting selfishly by choosing L. However, the strategy is another example of helping the client to change $\mathrm{B}$ by introducing changes into A.

- At line 150, I summarised the disturbance-related issues that Jane needs to address. However, I made an error in implicitly challenging the A about selfishness which enables her to conclude that she is not selfish by my definition. In doing so she moves away from working on challenging her irrational belief about selfishness.

- At line 152, I emphasized that in her situation she can't help but go against some important principle, but this again is an error in that it puts a positive gloss on A.

- At lines 237-254, I dealt with Jane's demand about having to go along with L's pressure, but in doing so I focused more on the unfairness of A where L wants her to make a big commitment without making one of his own. It would have been better if I focused more on her iB about his pressure and left alone the issue of L's unfairness.

- At line 255, instead of working with Jane's demand about having to bow to L's pressure, I suggested that she ask L to make a commitment to stay off drugs before she makes the commitment to go with him. She indicates at line 256 that she really likes this idea. This is problematic in that Jane might abandon belief work in favour of implementing this idea. Although I warn her to this effect at line 259 , the damage may have been done.

\section{Poor Use of Clinical Techniques}

Reading the transcript of my interview with Jane in its entirety, I realised that I implemented two techniques poorly. Thus:

- At lines 156-173, I employed the deathbed scenario as a decision-making aid prematurely. It did not clarify Jane's thinking much, but in my defence, I knew I had only one session with her and wanted to help her with her dilemma. 
Although the use of this technique was premature, it did reveal two other disturbance-related issues: (a) Jane's demand to have it all and (b) her demand to know that, if she chooses L, he will stick around. This technique would have been better employed after Jane had made greater strides at working on her emotional problems and, thus, given the one-off nature of the interview, it would have been better if I did not employ it at all.

- At lines 220-232, I used the devil's advocate technique to prepare Jane for going with L. This technique is designed to help her to strengthen her rational beliefs in response to my articulation of her irrational beliefs. I begin correctly by articulating her irrational belief about selfishness, but then I move away from the iB level to the inferential level at A by asking Jane how she could possibly trust L. I rescue matters at line 230 by expressing Jane's iB about uncertainty. But the error here is that I confused Jane by not carefully and consistently focusing the dialogue on her irrational beliefs.

When I conducted this interview in 1994, I had been an REBT therapist for 16 years. I have now been an REBT therapist for 30 years and I would like to think that my work with Jane would have been more elegant in that I would have focused more on her demands and would have worked on changing her irrational beliefs without changing A as I did so. This raises the interesting question concerning how REBT therapists change over time in their practice of REBT - a topic perhaps for a future special issue of the Journal of Rational-Emotive \& Cognitive-Behavior Therapy.

\section{References}

Ellis, A. (1994). Reason and emotion in psychotherapy: Revised and updated. New York: Birch Lane Press.

Ellis, A., \& MacLaren, C. (1998). Rational emotive behaviour therapy: A therapist's guide. Atascadero, CA: Impact. 